\title{
Migration and Financial Transfers: UK-Somalia
}

\author{
Anna Lindley
}

\begin{abstract}
Migrants' financial transfers have been estimated to be Somalia's largest source of revenue. The UK is believed to be a significant source of these financial transfers to Somalia. Drawing on preliminary ethnographic research in the UK during 2004, this paper firstly presents some empirical observations on the dynamics of these movements of people and money between the UK and Somalia and other parts of the Horn of Africa. Secondly, it asks, in contexts of forced migration, what is the relevance of the popular concept of migrants' financial transfers as part of a "transnational household livelihood strategy"? Notions of household, strategy, and what it means to send money in such contexts are critically reviewed. The analysis concludes with some challenges to common assumptions regarding refugees' economic actions.
\end{abstract}

\section{Résumé}

Les transferts financiers d'immigrants sont considérés comme étant la plus importante source de revenus en Somalie, et le Royaume-Uni serait le principal responsable de ces transferts. À partir de recherches ethnographiques effectuées au Royaume-Uni en 2004, l'article s'attarde d'abord à des observations empiriques sur la dynamique des déplacements de personnes et d'argent entre le Royaume-Uni et la Somalie ou d'autres parties de la corne d'Afrique. Dans le contexte de l'immigration forcée, l'article aborde ensuite la question de la pertinence du concept populaire de transferts financiers d'immigrants en tant que "stratégie transnationale des moyens de subsistance des ménages". Les notions de ménage, de stratégie et du sens lié à l'acheminement de sommes monétaires dans un tel contexte sont examinées d'un point de vue critique. L'analyse conclut par quelques remises en question des hypothèses concernant les activités économiques des réfugiés.

\section{Introduction}

$\mathrm{W}$

e do not think of refugees as helping to keep a country's economy afloat. We do not think of refugees as financing a telecommunications industry, providing for the basic needs of families abroad, paying for weapons for militiamen, putting equipment in hospitals. Yet these are all activities attributed to Somali migrants through the sending of money to Somalia. Financial transfers by migrants have been estimated to be Somalia's largest source of external revenue, competing with livestock exports and considerably larger than international aid flows. Annual transfers from Somali migrants in the UK, believed to be one of the largest sources of transfers, have been estimated at around nine times the UK's bilateral aid to Somalia. The uses and impacts of these transfers in Somalia and elsewhere in the Horn of Africa are complex, but a significant proportion meet the daily needs of families. ${ }^{1}$

Migrants' financial transfers to their country of origin are calculated to be the most stable and second-largest capital inflow to developing countries, and are increasingly highlighted in academic and policy research. ${ }^{2}$ However, rather less attention has been paid to the dynamics of migrants' transfers to countries in conflict situations. ${ }^{3}$ This paper highlights the fact that many Somalis recognized as refugees have taken on roles that are more commonly associated in the literature with economic migrants, namely, the sending of financial transfers for spending and investment in the country of origin. The first section presents some empirical observations on the movement of people (with a range of motivations and statuses) from Somalia to the UK, and the movement of money (shaped by various factors) from migrants in the UK to Somalia and the Horn of Africa. In the light of this evidence, the second section reflects on how the dominant micro-level model of 
migration and migrants' transfers as part of a "household livelihood strategy" - a concept which pervades many understandings of transfers to conflict-affected countries helps and hinders our understandings of the UK-Somali case. The third section reflects on common assumptions regarding the economic actions of refugees.

The paper draws on fifteen in-depth interviews with Somalis in the UK and conversations at community organizations, at special events, in family settings, and with customers of a money-transfer agency during 2004.

\section{The Movement of People and Money}

The Republic of Somalia was formed in 1960 from a British and an Italian colony and collapsed in $1991 .{ }^{4}$ Warlordism and inter-clan violence devastated parts of the country during the 1990s. In the north the secession of Somaliland and the regional administration of Puntland have provided relative stability for people devastated by violence. In parts of central and southern Somalia there are non-state authorities - clan elders, Islamic and regional groups, and even coalitions of business people - that provide a degree of stability, many supported by their own militia. Efforts to re-establish a functioning government based in the southern capital, Mogadishu, continue at the time of writing. In the latest Human Development Report, Somalia's gross domestic product (GDP) per capita is among the poorest in the world, life expectancy is forty-seven years, primary school enrolment is 14 per cent, and adult literacy is 18 per cent. Around one-sixth of Somalis live abroad, the majority in neighbouring countries, but some further afield. ${ }^{5}$

According to Sørensen, "Few source countries produce only asylum seekers or economic migrants." ${ }^{6}$ Historically, there has been a range of political statuses and migration channels among Somalis living in the UK. From the 1800s, the British Merchant Navy recruited workers from the Protectorate of Somaliland, and a few thousand ex-sailors and their families were already living in the UK by the 1980s, along with small numbers of Somali students. ${ }^{7}$ When the civil war broke out in the north of Somalia in 1988, many more Somalis applied for family reunion in the UK or claimed asylum. People have continued to seek asylum fairly steadily since the beginning of the conflict. In 2003, Somalis made 10 per cent of asylum applications, more than any other national group, and received 30 percent of all the grants of settlement to refugees. ${ }^{8}$ Today, there are Somali people who have become British citizens and people at all stages of the asylum process, including people who have had their asylum claim rejected but have not been deported to Somalia. ${ }^{9}$ Some Somalis moved to the UK after living in other rich countries, for example claiming asylum after losing jobs and status in the Middle East countries during the 1990s, or moving as EU citizens from the Netherlands and Scandinavia since the late 1990s. ${ }^{10}$

There appear to be considerable incidences of remitting across most political categories and migration histories mentioned above and across a variety of socio-economic situations. The young men from Somaliland who first sojourned as seamen in the UK rarely planned to stay, saving and then sending or taking money to their families in Somaliland, building their future there. Retired seamen who did remain in the UK have sent money from redundancy payments or state pensions to support relatives abroad or sponsor their travel to the UK. ${ }^{11}$ Many people who send money to Somalia came as refugees and are now working in different types of employment; for example, one man, now working for the local council, sends a regular amount every month to two uncles, because they helped to bring him up; he also sends money to twelve aunts, something small to one or two of them each month, and to two uncles on his mother's side on a quarterly basis (co-ordinating with two more uncles in the US who also support them). When we spoke, he had received an e-mail from a school friend who needed money; he did not know how this friend got hold of his e-mail address. "I had not thought to send money to him, but now I will have to include him this month." At the weekend, his wife works as a cleaner and he looks after the children as she also helps support relatives in Somalia. Other people who make transfers are reliant on state support; for example, a group of sisters I met transfer $\$ 300$ per month to their mother and a sick brother in Somalia. Some of the sisters are on income support and I asked one girl if she ever found it hard to make the payments. She responded emphatically that they have to send the money, that they work it out between them if one of them does not have quite enough, saying, "She can't work, can she? She's an old lady living with her sick son ... there's no pension [in Somalia]." While it is much less common for people on asylum support to remit money, it does sometimes occur, particularly when people have relatives in very difficult situations. Even some Somalis born in the UK or who arrived at a young age sometimes send money. For example, one girl in her twenties who moved to the UK when ten years old sometimes sends money to her aunt and her grandmother: "I'm not supporting them every month . . . so every six month I might just

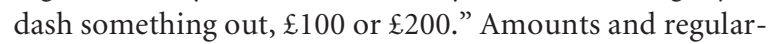
ity of family transfers vary considerably: people may send anything between $\$ 50$ and $\$ 1,000$ on a monthly basis, with most transfers clustered at the lower end of this range, ${ }^{12}$ but many migrants send less frequently, "what I can when I can," or in response to particular needs communicated by the recipient. 
To whom are financial transfers sent and for what? Family members are the commonest important group of recipients, with mothers and siblings featuring prominently as recipients. ${ }^{13}$ However, other relationships can also play a role. Family and business relationships often merge, with relatives often running or co-owning businesses started by migrants or living in and looking after property owned by a migrant. Many Somali import-export and construction businesses require financial transfers from partners or investors in the UK or other countries. There are also numerous migrant-supported health and educational projects in Somalia, with clan and community relationships playing a key role in mobilizing funds. For example, one subclan group mobilizes funds for a school in Somalia from the diaspora: each month, group members in each country are responsible for sending a certain amount to cover the total $\$ 6,000$ monthly running costs of the school. An e-mail list communicates news about the project and mobilizes the group in response to contingencies and to share gentle gossip and jokes. ${ }^{14}$ Clan and political allegiances have also at times mobilized funds for factional leaders and new political administrations, e.g. via clan collections made by groups of refugees to support militia - although people tend to say that the days of collecting money for warlords are over, that since the mid-1990s, people no longer trust the warlords to protect their families' interests. However, new political formations and leaders in the north continue to garner support from the diaspora, with attempts in recent years to raise funds in the UK for Abdullahi Yusuf as leader of Puntland (he has now been elected president of the new Somali parliament) and with the resounding verdict from the Foreign Minister of Somaliland, Edna Aden: "The disapora has brought Somaliland to where it is today." 15

These financial transfers, of varying amounts and regularity, from a range of political categories of migrant across a range of relationships, can be used for food, housing, health, education, to maintain livelihoods during difficult times, to extend livelihoods, to capitalize new income-generating activities, to invest in social networks and charitable initiatives, for political support. In the context of limited income-generating opportunities in Somalia, several Somalis I interviewed described transfers as "like a monthly salary" or "like social security" for recipients. Some interviewees who send money said how they hoped the money is used, but stressed that they sometimes have little control or knowledge over actual uses by family members. This, and some other aspects outlined above, do not easily fit with the concept that familial financial transfers are a "transnational household livelihood strategy."

\section{A “Household Livelihood Strategy"?}

How does the literature on migration explain migrant transfers? In the 1980s, in development economics, the definition of "household" shifted from "shared residence" to "mutual sustenance unit," which might include people located in different places as long as their principal obligations and commitments are to that household. In this context, the "new economics of migration" (NEM) focuses on the household as the main unit of analysis, and explains migration, at the microeconomic level, as a way to diversify the household's income portfolio in response to local constraints (in labour, credit, insurance, or other markets). ${ }^{16}$ In this model, migrants and non-migrants in the household share costs and returns of migration, so anticipated remittances are key in migration decisions, part of a "self-enforcing, cooperative, contractual arrangement."17 Effectively, migrant transfers occur as part of a household livelihood strategy.

In more recent years some interesting conceptual themes have been developing that are relevant to financial transfers to countries undergoing conflict, including Horst's exploration of Al-Ali's term "forced transnationalism" in the context of Somali migrants in Minneapolis, Riak Akuei's research underlining the remittance "burdens" on Sudanese refugees, and Al-Ali, Black and Koser's framework for analyzing factors affecting the transnational engagement of refugees based on research with Bosnian and Eritrean people. ${ }^{18}$ However, the concept of migration and migrant transfers as part of a "household livelihood strategy," while originally developed within an economic and functionalist paradigm, has proved particularly powerful and pervasive and is often invoked, both casually and carefully, to explain remittance-sending by people from conflict-affected countries. How does this approach help and hinder our understanding of migrant transfers in general, including to conflict-affected areas? My reflections focus on three areas: the notion of "household," the notion of "strategy," and the process of sending transfers.

Firstly, it is important to problematize the household unit. In terms of composition, in Somalia "almost every 'family' unit encompasses three or more households, which are interdependent in terms of the accumulation of resources and their distribution." 19 Moreover, in conflicts, household composition often changes radically, as family members may be killed, or displaced, or may just lose each other, and family members not strictly part of the "original" household can take on key roles. Non-household links clanship, business, friendship, community, philanthropic relationships - can also be the source of material and financial transfers. A woman who sent a fourteen-year-old niece to Europe with a smuggler cited the poor education available in Somalia as the main reason, and then said: "Her 
parents are poor, but we, the relatives, can foot the expenses involved ... It is our hope that she will support her family."20 Here, the girl's migration was clearly viewed as a collective investment, but a wider concept of family prevails. Gender, age, and social relations also shape the household's migration decisions. ${ }^{21}$ These relations can be dynamic: for example, Somali families would traditionally send sons as migrants, and when the conflict broke out, often families were concerned to get their sons out of the country to avoid the militia, but over time reportedly families increasingly prefer to send daughters because they are seen as better at "remembering their family" and sending money home. ${ }^{22}$

Secondly, it is also important to problematize the notion of migration and transfers as part of a coherent strategy in a given context. The new economics of migration was developed to explain contexts of labour migration. While elements of force have certainly been uppermost in the exodus from Somalia under conditions of conflict, it is important to acknowledge that there are elements of choice and force in both the most constrained flight from violence and more work-motivated movements. ${ }^{23}$ As highlighted by the concept of "human security," the empirical boundaries of countries "at peace" and countries "at war" can be more blurred than we often think.

There are parts of the former Republic of Somalia that are quite possibly more secure for a child growing up than some of Brazil's slums or Kenya's refugee camps. This does not belittle the human disaster of civil war, it rather testifies to the existence of complex forms of insecurity and violence across the world.

In all this, people are not only geographically, but also socially, politically, and economically situated. In complex and changing structural contexts, position is key: it can determine whether people stay or go, and where they are able to go. Migration to the UK is now dependent on the mobilization of not-insubstantial financial resources, and family assistance is common: to smuggle a person today costs $\$ 4,000$ to $\$ 10,000 .{ }^{24}$ According to a Somali aid worker in Hargeisa, "Each person here would sell their soul to get a visa - they would sell their house, their camels, their possessions, their gold. They are happy to pay up to US\$10,000 to an agent and take a gamble to get someone abroad." ${ }^{25}$ Despite the extreme context of this case, it fits with the NEM model as an example of a collective family investment strategy based on the anticipation of financial returns.

Moreover, the term "strategy" - defined as a long-term plan to achieved a particular $\operatorname{aim}^{26}$ - implies a degree of self-aware intent. This fails to capture the complexity of migration from countries undergoing conflict. Some people flee conflict and persecution in an unpremeditated fashion (tactics?); many also leave as the result of a more meditated decision as threats increase (strategy?). Often migration is staged, beginning with a pretty desperate flight to a neighbouring country, then a more meditated decision to move to a richer country. Once people have escaped immediate danger, they often feel the same concerns as migrants from peaceful contexts: the wish to earn more money, to find better opportunities, and so on. Van Hear suggests that transnational connections between family members in the three domains of refugee protection (country of origin, country of first asylum, country of resettlement), signficant for many Somali families, represent "enduring" if not official, "durable" solutions to displacement. ${ }^{27}$ However, the spreading out of many families often becomes a strategy - in the sense of a "long-term plan" only after migration has occurred. To say that migrant transfers are part of a "migration strategy" in these complex contexts smacks of ex post rationalization. Going back to the NEM model, it remains unclear how much of a role anticipated transfers actually play in prompting migration from conflict-affected countries. In some cases, anticipated remittances do clearly make a difference - this is illustrated by the varying market prices of migration: "agents in Mogadishu can charge double the price for smuggling Somali girls to Italy because the girls get jobs as housekeepers and can start sending money home immediately." 28 What is clear is that whether Somalis have been thinking ahead to future transfers or not when moving to the UK, whether leaving Somalia or other countries of residence for the UK was "desperate" or "calculated" and supported by their family or not, transfers often still take place.

Thirdly, what about the senders? The NEM approach tends to normalize financial transfers as an integral part of migration: migration is effectively predicated on anticipated economic returns. Most studies on remittances conduct research in the country of origin, with remittancereceiving households; researchers are mainly interested in the impact of remittances and tend to assume that, within certain parameters, the sending of remittances occurs pretty automatically in response to the needs of the receiving household. Thus the process of sending transfers is rarely problematized and the impact of transfers on the lives of senders is rarely considered. The source, patterns, and sustainability of remittance transfers in general, and particularly to countries undergoing conflict, remain underresearched.

More detailed economic studies have conceptualized remittance behaviour in four main ways. ${ }^{29}$ Firstly, altruism or enlightened self-interest: concern for the family and investment in family relationships are socio-economically useful if you go home. Secondly, self-interest: you might wish to 
cultivate good relations with your parents to secure your inheritance, or you might prefer to invest your savings in your home country and trust your family to handle this. Thirdly, co-insurance: when things are bad at home, you send them remittances; when things are bad in the host country, you can go home. Fourthly, loan repayment: your family financed your upbringing / education / migration and you owe them. To some extent, we can recognize these motivations to remit when examining the UK-Somali case. However, this case also highlights that we should not focus just on the dynamics between senders and recipients: the material parameters of the migrant and the recipient also shape the sending process, in this case particularly the migrant's income level, household composition in the UK, and the income, location, and security situation of the recipient, and whether they receive help from other family members, can also shape financial transfers. Information, or means of contact, would also appear to be an important factor in shaping particularly family transfers: reportedly, remittances to Hargeisa tripled in 1996 when telephone services became widely available. ${ }^{30}$

The relevance of such parameters is particularly salient where people are migrating from conflict-affected countries. Hyndman, researching displacement from Somalia and humanitarian responses, points out that refugees do not easily fit the "migrant transnational" template: "Poststructuralist approaches which are attentive to the hypermobility of capital in relation to the markedly restricted movement of members from the displaced diaspora pose a stark challenge to the often compelling analyses of some 'travelling theorists'." It is clear that "[d]ifferent social groups have distinct relationships to this anyway differentiated mobility: some people are more in charge of it than others: some initiate flows and movement others don't; some are more on the receiving-end of it than others; some are effectively imprisoned by it." ${ }_{11}$ This analysis resonates with empirical evidence on the sending of financial transfers by Somalis in the UK. Some are indeed urbane "transnational entrepreneurs," businessminded people creatively deploying often earlier-accumulated resources and their transnationalism to get on in the world; others are vulnerable people struggling to fulfill, through great self-sacrifice, the obligation of keeping family members from starvation. In the Netherlands, anecdotal evidence suggested that newly arrived Somali women who were seeking asylum, in many cases single mothers, often remitted half of their asylum allowances to help the rest of their family, with visible repercussions on the nutrition and health of the children under their immediate care in the host country. As a Somali health worker put it, "[Their children] were eating bread and jam too often." ${ }^{32}$ For Somalis in the UK, transfers are often a significant factor in their livelihoods, with reports of people working two or three jobs on low wages and remitting high proportions of their earnings. ${ }^{33}$ Some people talk about not being able to make any savings in the UK because of their commitments to family at home. There are clear tensions between economic prospects in the host country and support of relatives in Somalia. One fortyyear-old father, a government employee and homeowner, told me his brother had phoned several times during a recent drought for him to send money to pay for the family's livestock to be trucked to the next waterhole, as the camels would not make it if they had to walk. After a couple of such payments, he had wanted to ask if it was really necessary, but could not really find the words to ask, so he tried to say as little as possible. As he pointed out, laughing, his brother would not appreciate being told that he has a mortgage to pay. Many senders whose family members depend on them for subsistence aspire one day to send a lump sum to capitalize a sustainable incomegenerating activity for the family in Somalia, "so they don't need to bother you any more." Some women use rotating fund systems among clan and family members: the strong social trust among participants and the commitment to contribute to such a fund is respected and understood by relatives in Somalia, and it is easier for participants to put off requests than when their money is in a bank and could easily be withdrawn. Through regular contributions, each participant obtains a lump sum to remit or to spend on a major purchase such as a car in the $\mathrm{UK}^{34}$

Interviewees express a strong sense of moral and social obligation to remit: "It's a must," "You put yourself in their shoes," "In Somalia, you eat with your brother when he has money;" and some also invoke a related sense of social pressure to remit, from family and home community but also within the diaspora. One interviewee told me that his cousin has a good job in a shop in the UK but he was not helping his mother in Somalia, so the interviewee, who was sending her money, forced the cousin to speak to her on the phone. Now the cousin sends her about $\$ 200$ per month; the interviewee physically accompanies him to the cash point on payday and himself takes the cash directly to the money transfer agency. These examples illustrate that the process of sending transfers can be far from straightforward for the migrant.

These are some of the issues raised by the UK-Somalia case regarding the "transnational household livelihood strategy approach" approach to understanding migrant transfers. It is important to note that many of these issues are general problems with the economic functionalism of 
the "new economics of migration" and apply in many other contexts of migration and transfer, involving countries formally at peace - although these problems are thrown into particularly sharp relief by the UK-Somalia case.

\section{Concluding Reflections}

The financial transfers explored here represent the engagement of Somali migrants in a transnational process, the social, economic, and commercial dynamics of which challenge some common assumptions about the economic actions of refugees. Crisp has pointed to a tendency in the literature to treat refugees as a separate case, in a way that can exaggerate differences between refugees and other migrant groups. ${ }^{35}$ A particularly important example of this has been the fact that remittance sending is generally associated with "economic migrants" rather than also being a recognized activity undertaken by refugees. Research on the economic actions of people categorized as refugees tends to focus on those enacted within the host state, whether regarding refugee livelihoods in countries of first asylum or refugees' fortunes in, for example, the UK labour market.

Refugees in the West are often assumed to be too isolated and deprived to make financial transfers. While isolation and deprivation certainly do form part of the experience of many refugees in the UK, this does not preclude many refugees saving and sharing income with family overseas; moreover, even small amounts of money can be of considerable significance by overseas standards, and particularly so in countries wrought by conflict.

The debate on migration and asylum in Europe remains hyperpoliticized and largely domestically focused or aid focused. In the rich European countries that offer asylum to some people from states undergoing conflict, the economic actions and the elements of economic motivation of those seeking asylum are too often either demonized or denied. Yet refugees' earnings and in some cases welfare receipts may be remitted to provide support to families very badly affected by conflict, often at considerable cost to the refugee. The tentative evidence indicating that Somalis in the UK might send per year nine times the amount of the UK's bilateral aid budget to Somalia is food for thought. These financial transfers in no way substitute for just distribution of tax revenue or allocation of international aid to poor people, and their complex effects are beyond the scope of this article. It is worth remembering, however, that beyond failed political regimes and beyond international aid, people who have left countries affected by protracted conflict and state collapse can be key actors in ongoing transformations, of many types, that are occurring their places of origin.

\section{Notes}

1. Financial transfers to Somalia are estimated at between US $\$ 700$ million and $\$ 1$ billion per year, US $\$ 360$ million of which are estimated to go to family members for food, shelter, clothing, schooling, health care, and other necessities; see Abdusalam Omer and Gina El Koury, "Regulation and Supervision in a Vacuum: The Story of the Somali Remittance Sector," Small Enterprise Development 15 (2004): 44-52. International assistance to Somalia totalled US $\$ 271,604,400$ in 2003, according to Somalia Aid Co-ordination Body, Donor Report 2003 (Nairobi: SACB, 2004). Somali migrants in richer countries also send money to family members in other countries, particularly Egypt, Ethiopia, and Kenya. Somalis in the UK transfer around US $\$ 12$ million per month to Somalia, according to Abdusalam Omer, A Report on Supporting Systems and Procedures for the Effective Regulation and Monitoring of Somali Remittance Companies (Nairobi: UNDP, 2002). The basis for this estimate of remittances from the UK is unclear and would seem to be based on estimates from remittance companies, and is likely subject to a wide margin of error. The UK's total bilateral assistance to Somalia is around US\$15 million for the year 2004-05; see Department for International Development, Press Release: UK provides more funding to Somalia's humanitarian needs, London: DFID, <http://www.dfid. gov.uk/news/files/pressreleases/ pr-somalia-full.asp> (accessed December 3, 2004).

2. For example, Dilip Ratha, "Workers' Remittances: An Important and Stable Source of Development Finance," in Global Development Finance, ed. The World Bank (Washington, D.C.: World Bank, 2003). 157-75.

3. Relevant work includes: Nadje Al-Ali, Richard Black, and Khalid Koser, "Refugees and Transnationalism: The Experience of Bosnians and Eritreans in Europe," Journal of Ethnic and Migration Studies 27 (2001): 615-34; Nicholas Van Hear, "Sustaining Societies under Strain: Remittances as a Form of Transnational Exchange in Sri Lanka and Ghana," in New Approaches to Migration? Transnational Communities and the Transformation of Home, ed. Nadje Al-Ali and Khalid Koser (London: Routledge, 2002); Cindy Horst, Transnational Nomads: How Somalis Cope with Refugee Life in the Dadaab Camps of Kenya (PhD thesis, University of Amsterdam, 2003); Paul Collier, Policy for Post-Conflict Societies: Reducing the Risks of Renewed Conflict (Washington, D.C.: World Bank, 2000); Stephanie Riak Akuei, "Remittances as Unforeseen Burdens: The Livelihoods and Social Obligations of Sudanese Refugees (report in the series Global Migration Perspectives, ed. Jeff Crisp and Khalid Koser, Global Commission on International Migration, Geneva, 2005).

Considering Displacement, Family and Resettlement Contexts in Refugee Livelihood and Well Being. Is There Anything States or Organisations Can Do?" (London: University College London, 2004).

4. From 1969, the country was ruled by General Siyad Barre, whose "scientific socialist" regime retained power in latter years through a mixture of repression, manipulation of clan affiliations, and harvesting geopolitical rent from the Cold 
War superpowers. Civil war broke out in the north in 1988, and Barre was ousted in the south in 1991.

5. See UNDP, Human Development Report 2001 Somalia (Nairobi: UNDP, 2001). Recent population estimates vary considerably, which indicates just how circumspect you have to be about statistics on Somalia.

6. Ninna Nyberg Sørensen, "Opportunities and Pitfalls in the Migration-Development Nexus: Somaliland and Beyond" (DIIS Working Paper 2004/21, Danish Institute for International Studies, Copenhagen, 2004).

7. Shamis Hussein, "Somalis in London," in The Peopling of London, ed. Nancy Merriman (London: Museum of London, 1993) 163-68; Save the Children Fund Wales Division, The Somali Community in Cardiff (Cardiff: Save the Chidren Fund, 1994).

8. See Home Office, Control of Immigration Statistics United Kingdom 2003 (London: The Stationery Office, 2004). A grant of settlement allows someone subject to immigration control to remain in the UK indefinitely and is described as "the main available measure of longer term immigration of persons subject to immigration control." Since 1998, people recognized as refugees are simultaneously granted settlement and those granted Exceptional Leave to Remain can apply for settlement after four years' residence with that status.

9. Around two-thirds of Somali asylum applications that received an initial decision in 2003 were refused, but many will succeed on appeal. See Home Office, Control of Immigration Statistics United Kingdom 200, and Anushka Asthana, "Living in Fear: My Week with the Hidden Asylum Seekers," Observer, March 28, 2004.

10. Katrine Bang Nielsen, "Next Stop Britain: The Influence of Transnational Networks on the Secondary Movement of Danish Somalis" (Working Paper No. 22,: Sussex Centre for Migration Research, Falmer, March 2004).

11. Field notes, December 2004; David J. Griffiths, Somalis and Kurds in London: New Identities in the Diaspora (Aldershot: Ashgate, 2002); and E. Silveira and P. Allebeck, "Migration, Ageing and Mental Health: An Ethnographic Study in Perceptions of Life Satisfaction, Anxiety and Depression in Older Somali Men in East London," International Journal of Social Welfare 10 (2001): 309-20.

12. Interviews.

13. Interviews.

14. Field notes, August 2004.

15. Field notes, March, April, and December 2004; and David Phelps, Dee DePass, and Joy Powell, "Minnesota Somalis Send Millions Back to East Africa," Star Tribune, November 19, 2000.

16. J.E. Taylor, "The New Economics of Labour Migration and the Role of Remittances in the Migration Process," International Migration 37 (1999): 63-86.

17. Oded Stark and Robert Lucas, "Migration, Remittances and the Family," Economic Development and Cultural Change 36 (1988): 465-81.

18. See references in note 3; also Cindy Horst, Money and Mobility: Transnational Livelihood Strategies of the Somali Diaspora,
Global Migration Perspectives No.9 (Geneva: Global Commission on International Migration, 2004).

19. Khalid Medani, Report in Internal Migration and Remittance Inflows: Northwest and Northeast Somalia (Nairobi: UN Coordination Unit and Food Security Assessment Unit, 2000), 16.

20. Lucy Hannon, A Gap in Their Hearts: The Experience of Separated Somali Children children (Nairobi: Integrated Regional Information Networks, United Nations Office for the Coordination of Humanitarian Affairs, 2003) [emphasis added].

21. Sylvia Chant and Sarah A. Radcliffe, "Migration and Development: The Importance of Gender," in Gender and Migration in Developing Countries, ed. S. Chant. (London: Behaven Press, 1992).

22. Interviews; Lucy Hannon, A Gap in Their Heart; and Cindy Horst, Transnational Nomads.

23. Nicholas Van Hear, New Diasporas (London: UCL Press, 1998); Anthony H. Richmond, Global Apartheid: Refugees, Racism and the New World Order (Oxford: Oxford University Press, 1994).

24. Interview, April 2004; and Lucy Hannon, A Gap in T heir Hearts, 64.

25. Lucy Hannon, A Gap in Their Hearts [emphasis added].

26. <http://www.askoxford.com/concise_oed/household?view $=\mathrm{uk}>$.

27. Nicholas Van Hear, From Durable Solutions to Transnational Relations: Home and Exile among Refugee Diasporas (Geneva: New Issues in Refugee Research, UNCHR, 2003).

28. The price for smuggling a girl from Somalia to Italy is $\$ 7,000$, compared with \$3,500 to other European countries; see Sørensen.

29. Gary Becker, "A Theory of Social Interactions," Journal of Political Economy 82 (1974): 1,063-1,093; Andres Solimano, "Workers' Remittances to the Andean Region: Mechanisms, Costs and Development Impact" (Conference on Remittances and Development, Multilateral Investment Fund - Inter-American Development Bank, May 2003, Quito, Ecuador); B. Poirine, "A Theory of Remittances as an Implicit Family Loan Arrangement," World Development 25 (1997): 589-611; Oded Stark and David E. Bloom, "The New Economics of Labor Migration;" and Oded Stark and Robert Lucas, "Migration, Remittances and the Family."

30. Ismail I. Ahmed, "Remittances and Their Economic Impact in Post-war Somaliland," Disasters 24 (2000): 380-89.

31. Jennifer Hyndman, Managing Displacement: Refugees and the Politics of Humanitarianism (Minneapolis: University of Minnesota Press, 2000), 151. She quotes Doreen Massey, Space, Place and Gender (Cambridge: Polity Press, 1994)

32. Field notes.

33. Interviews.

34. Interview, November 2003. A man told me about one rotating fund in really enthusiastic detail: he was hoping to join, but was not sure if the women would trust him, as he is a man.

35. Jeff Crisp, Policy Challenges of the New Diasporas: Migrant Networks and Their Impact on Asylum Flows and Regimes (Oxford: Transnational Communities Programme, 1999). 
Anna Lindley is a doctoral student at Oxford University, based at the International Development Centre and at the Centre on Migration, Policy and Society. Her research focuses on migration, remittances, and related political contexts. An earlier version of this paper was presented on the Migration-Asylum Nexus panel at the International Association for the Study of Forced Migration $9^{\text {th }}$ International Conference, São Paulo, 10 January 2005, and benefited from participants'suggestions. The author welcomes comments: anna.lindley@qeh.ox.ac.uk. are credited and the original publication in Refuge: Canada's Journal on Refugees is cited. 